\title{
The SOV Regulation. A new criminal code regulation measured against the behavioural sciences
}

\author{
T.I. Oei, MD., PhD. \\ Professor of Forensic Psychiatry \\ Faculty of Law \\ Tilburg University \\ The Netherlands
}

\begin{abstract}
The so-called Psychopath Laws were introduced in The Netherlands at the beginning of the 20th century, with the purpose of ensuring the humane care and detention of disturbed criminals, and in so doing to prepare them for reintegration into society. In practice, however (especially in the early period following implementation of the legislation), all kinds of vagabonds, drunks and tramps were detained in order to bring them in line with the social order of the time - in other words, to keep them in custody so that they would no longer constitute a danger to society. These Psychopath Laws became, in fact, an instrument by which nuisance elements could be put behind bars. And once again we meet a similar 'nuisance criteria' in 2002, when the so-called SOVRegulation came into force. This regulation has been incorporated into legislation governing the Legal Detention of Addicts (known in The Netherlands as the SOV Law), Statute Book 2001, no. 28.

There are problems surrounding the question of whether the SOV regulation is actually used solely, or primarily, to put nuisance-element justiciables behind bars. SOV can only be effective if there are enough behaviour-expert arguments to support it. The field of behaviour-expertise is challenged to remain alert whereby justiciables are guaranteed the treatment they need.
\end{abstract}

\section{Introduction}

The so-called Psychopath Laws were introduced in The Netherlands at the beginning of the 20th century, with the purpose of ensuring the humane care and detention of disturbed criminals, and in so doing to prepare them for reintegration into society. In practice, however (especially in the early period following implementation of the legislation), all kinds of vagabonds, drunks and tramps (Hofstee 1987) were detained in order to bring them in line with the social order of the time - in other words, to keep them in custody so that they would no longer constitute a danger to society. Under Belgian law, the govern- 
ment had instituted a law whereby beggars, vagabonds and pimps, could be detained, the primary purpose being to safeguard public order and security. These psychopath Laws became, in fact, an instrument by which nuisance elements could be put behind bars. And once again we meet a similar 'nuisance criteria' in 2001, when the so-called SOV-Regulation came into force. This regulation has been incorporated into legislation governing the Legal Detention of Addicts (known in The Netherlands as the SOV Law), Statute Book 2001, no. 28. (See also DD-Delikt en Delinkwent-, 31 (2002), 6, p. 600 and further.) It has thus been possible, since 1 April 2001, to impose compulsory detention on drug addicts for a maximum duration of 2 years, calculated as from the day on which the decision of the court became irrevocable. The target group comprises hard drug addicts who have usually committed a series of offences, and have thereby become a serious 'nuisance element' in the society around them; they are largely people who have been found guilty of offences often qualified as "recurring criminality", such as petty theft (including shoplifting, and [motor]bike thefts), car thefts, car break-ins, pick-pocketing, and private and commercial property burglaries. The judge can take account of the period of time the accused has been held on remand, although he is not bound to do so (art. 38n, Stat.). What is new here is that the judge can impose the sentence on the instruction of the Department of Public Prosecutions (art. 38m, para 1, Penal Code, hereinafter PC).

What conditions must the defendant satisfy before such a sentence can be imposed?
1. The offence committed by the accused must be one for which he can legally be held on remand (38m, para sub.1, PC).

2. In the previous five years, the defendant must have been sentenced for an offence for which a custodial sentence or a community service sentence was imposed ( $38 \mathrm{~m}$ para 1 , sub. 2 , PC). The guidelines issued by the College of Attorney Generals (valid from 1 April 2002 - 1 April 2005) also include an extra criterion for the imposition of the SOV-regulation, i.e. in the previous five years, no less than 10 charges must have been served against the defendant.

3. The accused is a drug addict, i.e. a person who on the basis of facts and circumstances, appears to be physically and psychologically dependent on one or more illegal substances (art. 38m, para 3, PC), as stated in List 1 attached to the Opium Act.

4. Serious consideration has to be taken of the fact that he will commit a further offence, as a result of his addiction (art. $38 \mathrm{~m}$, para 1 , sub. $2 \& 3, \mathrm{PC})$.

5. The safety of persons and property demands the imposition of such a sentence (art. $38 \mathrm{~m}$, para 1, sub. 4, PC).

The aim of this contribution, from a behavioural expertise viewpoint, is to place a number of question marks around this practice, insofar as behaviour experts have a part to play in the enforcement of the SOV Law. Can a forensic behaviour expert with conscientious objections -for ethical, religious or other personal reasons- justifiably refuse to cooperate in the implementation of this law? If not, what must be expected of him? Double-reporting, yes or no? Evaluation reporting? Is the determination of the recidive risks part of such Pro Justitia reporting? Is 'nuisance' a behav- 
ioural expertise concept? What connotations, then, should be attached? How 'soft' is the participation of the forensic behaviour expert in respect of the implementation of the SOV law?

Is not the informing-function of the forensic psychiatrist precisely a task which stands apart from the question of whether or not a sentence or regulation is subjectively acceptable? What is the relationship of the forensic behaviour expert to the social awareness of valid norms and values?

\section{What is the SOV and why is there resistance to it?}

The SOV is an experiment grounded in law. For the moment, there are no places available for women and illegal inhabitants of the Netherlands. In addition, only young men above the age of 18 years and longterm residents of Amsterdam, Rotterdam, Utrecht, Arnhem, Nijmegen, Den Bosch, Eindhoven or Maastricht, can be given a custodial sentence of this kind. Some of the planned custodial facilities have not yet been completed.

The regulation is designed partly to contribute to the solution of the accused's drug addiction problem in the interests of returning him to society, and partly to bring a halt to his recidive behaviour (art. $38 \mathrm{~m}$, para 2, $\mathrm{PC}$ ). According to the legislators, the nuisance element and the addiction itself, together justify compulsory detention.

The behaviour expert with conscientious objections, will have just as many problems with working as adviser to the judge in the case of the SOV law, as with the TBS (= hospital order detention) legislation. Both, after all, are legal regulations designed to safeguard the safety of the general public.
In legal terms, however, there are a number of objections (Ekelemburg 2001, Kelk 1999, Mevis 1996, Van Kalmthout 2000, Vegter 2001a, Vrolijk 2001) in terms of the 'nuisance' criterion for imposing such a sanction. It is a fact that addict-care also fulfils a kind of 'trash-can function' for the GGZ (= Mental Health Care Service). The criminal proceedings of the late Middle Ages and the 16th century, are interesting. The 'nuisance' element was reason enough for the (family) of those concerned to intervene. From the 16th century onwards, however, reconciliation (by means of petitions, letters of reconciliation and improvement processes) -as prior conditions for the granting of royal clemency, which did not imply that there was no guilt- became an integral part of the whole legal prosecution process. The more this ex-officio prosecution began to become firmly established, the more the position of the victim's family decreased, as also the liability of the perpetrator's family in the improvement process.

The concepts of duress and pressure have, nonetheless, occupied the minds of the medical profession for centuries. How far can we go in giving medical treatment to the people in our care? Fortunately, the legal position of the patient is well protected here. As far as detainees and justiciables (everybody who needs legal help) are concerned, the necessary conditions have also been created whereby their needs and possibilities have been properly defined, from the medical point of view as well, by means of such legislation as the Basic Penitentiary Law (PBW) and the Medical Treatment Agreement Law (WGBO). What counts in terms of SOV and TBS legislation, is the risk to property and citizens. It will not be the first time that a chronically addicted drug-user under the influence of hard drugs, whether 
or not in combination with alcohol, commits a criminal offence (be it serious or petty).

There is also every reason, therefore, to subject a chronic drug addict to behavioural expertise testing in order to determine whether or not he falls within the confines of SOV legislation.

It appears that in practice, there are many physicians in The Netherlands who find it difficult to provide an appropriate psychiatric diagnosis for chronic personality-disorder drug-abusers. In the United States, wide use is made of the Diagnostic and Statistical Manual of Mental Disorders (DSM-IV), in which drug-dependence (addiction) is classified as an Axe 1 disorder, a situation perfectly acceptable to USA psychiatrists.

There are two main reasons for this difference in attitude between the American and Dutch medical professions. They rest on both social and scientific grounds. In the USA, the medical profession in the 1950s became more familiar than their Dutch counterparts with developments in scientific insights into the effects of substances such as alcohol, stimulants and other drugs (Crome 2001), and for this they were able to draw on the findings of research carried out at the National Institute of Mental Health (NIMH). This was also helped both by the fact that drug-dealing and drug-abuse were regarded as 'sick', and that strict prohibitive laws were introduced to combat them. In England too addiction research lagged behind that in the United States, due to the lack of a national drug research policy.

It is illegal in America, for instance, for minors to drink alcoholic beverages (note the recent conviction of the American President's daughter). Another reason was that the acceptance of addiction-care and the work of drug clinics as 'professional' in The Netherlands, was blocked by the relatively low status accorded to them. Medical interest in the care of drug-addicts was just as low as the appreciation, for instance, of the work of a doctor working in a baby-care clinic. It also had to do with the fact that The Netherlands had only a very limited addiction-care research tradition. Of course, studies on the effects of various drugs were occasionally carried out in some Dutch preclinical pharmacological research institutes, although there was hardly any clinical research, as such, despite the fact that some psychiatrists invested a great deal of time on the social and scientific care of alcoholics (for example, W.K. van Dijk and J.H. van Epen). More ideologically orientated social scientists made noble attempts to give the (social) tolerance of drug-abuse a scientific foundation. Clinical interest in addictioncare research is fairly new, and it was the Jellinek Clinic (for example, P.J. Geerlings, J. van Limbeek) especially, as also the Bouman House and the establishment of academic Chairs in this field (for example, W. van den Brink and G.M. Shippers), which ultimately provided the impetus for this development.

Addiction-care, in terms of organisation, in The Netherlands is currently more rooted in the national Mental Health Care system as a whole. This has been facilitated by merging the Mental Health Care Centres with the Alcohol and Drug Centre (CAD); one such example is 'Parnassia' in The Hague, which also houses a drug-addiction centre. Whether or not this kind of integrated addiction care service within the mental health care sector will also result in further acceptance of addiction as a field of medical research, remains to be seen. One thing is certain, however: the political 
vision of addiction-care being an important right of (addicted) citizens to receive the necessary attention and treatment, with all the consequent financial support, will influence the scientific development and emancipation of this specialised field within medicine.

Some people feel that this kind of social re-valuation of addiction-care actually goes too far. That an addict, by definition, suffers from a disorder, is also an unacceptable viewpoint for many. There are, after all, all kinds of weekend cocaine-users who are perfectly decent citizens who do no harm to anyone? That arguments of this kind provide sufficient ground on which to refuse to cooperate in the implementation of legislation, carries little conviction for me, and is disputable at best. As a forensic psychiatrist, it seems obvious to me that I will always give the courts the benefit of my advice. If a problem does arise, the forensic behaviour expert can always withdraw his cooperation, so long as he is able to recommend a qualified professional to take his place in the courtroom. If the behaviour expert sees 'overall' problems in his role as adviser to the court in cases involving SOV legislation, then all that remains to him (advice only) is to avoid or leave the forensic working area altogether.

\section{What, in terms of behaviour expertise, is needed for this?}

The well-grounded advice of a behaviour expert is obligatory (i.e. no multi-disciplinary reporting -an examination carried out by two behaviour experts, including a psychiatrist- such as is the case in TBS cases), that is no more than one year old, unless the Public Prosecutor and accused agree to older reports (art. $38 \mathrm{~m}$ para. 4, PC). The above-mentioned guidelines issued by the College of Procurator Generals, state that this report must give insight into the duration and severity of the addiction, the degree to which the accused has previously participated in programmes to 'kick' his addiction and whether or not they worked, in how far there is any realistic expectation that the accused will voluntarily complete a programme designed to help him conquer the drug habit, and whether or not there are any psychic or psychiatric problems which lessen, or exclude, his suitability for participation in an SOV-facility programme. If the accused refuses to cooperate in the reporting procedure, then the regulation can be imposed without it. In imposing the regulation, the judge takes cognizance of the content of the remaining advice and reports in respect of the accused, as also the number of offences he had already committed (art. $3 \mathrm{~m}$, para 4,5 and $6, \mathrm{PC})$. In the case of AMvB (Algemene Maatregel van Bestuur $=$ Order in Council), further regulations will be established regarding the legal position of those on whom the regulation has been imposed.

It is important that the regulation can also be imposed conditionally. The guidelines of the College of Procurator Generals already state that the Public Prosecution Department will only demand unconditional SOV as a final resort. Only if it becomes apparent that there is absolutely no willingness on the part of the accused to participate voluntarily in an effective programme to treat his addiction problems, will the SOV be imposed unconditionally. If the accused then changes his mind and agrees to take part in a programme, the regulation may or may not be imposed conditionally, unless it appears from the behaviour expert reports that there is no realistic expectation 
that the addict will actually complete such a programme on a voluntary basis. If the regulation is imposed conditionally, the judge is empowered to set conditions concerning the behaviour of the accused, and to do so in the interests of safeguarding the safety of persons or goods, whereby the probationary service can be instructed to give the necessary help and support to ensure that those conditions are fulfilled (art. 38p para 4. PC). These conditions could entail allowing the accused to receive ambulatory or intra-mural treatment. Admittance to an institution takes place in this connection for a length of time -no longer than two years- determined by the judge. The accused must then declare himself willing to undergo the treatment (art. 38p, para 5., PC). The conditions can be changed, supplemented or withdrawn at any time during the period of the sentence. The probation period will last for a maximum of 3 years. If a condition is not fulfilled, the judge may, at the demand of the Public Prosecutor, order that the regulation be imposed all the same.

\section{Where is the SOV implemented?}

A new category of institution has been added to the PBW in art. 9, namely an addict-care centre. Art. 10a of the PBW makes provision for the Public Prosecutor to nominate a remand prison as an addiction care centre, or an addiction care centre as a remand prison. A new chapter covering IVA addiction care, has been added to the PBW; it includes a provision whereby the director of such an institution should prepare a care plan within three months of the detainee's arrival, and as far as possible in consultation with him (art. 18a PBW). The director will also evaluate the detainee's progress at least once every six months. If the judge, when imposing the sentence, has decided that the Public Prosecutor should inform him within a period of time determined by him, about its continuation and implementation, the first evaluation will take place before that period has passed. A report will be made of this evaluation and will be discussed as soon as possible with the detainee; if the detainee is of the opinion that this report is factually incorrect or insufficient, he has the right to submit his own written commentary on it. If the evaluation report is supplemented or improved contrary to that stated in the detainee's commentary, it is the task of the director to ensure that the commentary is stapled to the report (art. 18c PBW). The Public Prosecutor will submit a report regarding the efficacy and effects of this law in practice, to the States General (= the Dutch Parliament) within three years of the sentence being implemented, and again after each subsequent third year.

\section{Discussion}

The Public Prosecutor shall, if required, demand the imposition of the regulation. Firstly, however, he will ask a behaviour expert whether or not the necessary conditions have been met. The Forensic Psychiatric Service (FPS) is an extremely important link in the chain; via the consultation letter (previously known as the report) addressed to the Public Prosecutor, the FPS may or may not conclude that deeper Pro Justitia reporting should take place. In normal circumstances, this will occur within the context of the SOV regulation, provided no serious psychiatric problems come to light. This kind of consultation letter is 
necessary in order to determine, or exclude, any possible psychiatric disorder. On the basis of the first examination, the psychiatrist will always need to legitimize the need for a more comprehensive behaviour expertise examination (van Kordelaar 2002. See also the Explanatory Memorandum on the Order in Council (ambv) on the WGBO, Statute Book 2000, 121, p.11; compare further note 4, Proces 2001, p. 158 , in which the first discussion with the behaviour expert is legitimized on the basis of the consultation letter). The study carried out by Van Kordelaar, also examined a procedure of this kind. Also the 'Best Practice' (2001) of the national Forensic Psychiatric Service which applies the consultation letter procedure as the first discussion with the psychiatrist during the arraignment by the examining judge or the Public Prosecutor, or in the context of the judicial hearing.

It can also occur that the Public Prosecutor, in addition to psychiatric pathology, requests a Pro Justitita report (prepared by a psychiatrist and a psychologist, a procedure which is also known as 'double reporting'), the purpose of which may, or may not, be to enable the imposition of another, non-punitive, sentence (such as a TBS hospital order, with or without compulsory treatment).

There are, however, all sorts of snags attached to the theoretical foundation, as well as to the practical implementation of the SOV regulation.

We see from the pre-SOV regulation history, that in the last stage of its being discussed in Parliament, there was a shift from the need for an addiction-expert as reporter to a psychiatrist as reporter, as occurred during the development process of the regulation, as is laid down in the
Explanatory Memorandum. The SOV was, in fact, never intended for seriously disturbed addicts. This means, on the one hand, that if the addict is not examined by a behaviour expert, it is in the interests of the addict to claim that he is suffering from some kind of psychiatric disorder, so that he can avoid the imposition of the SOV regulation, and be given a short prison sentence instead. On the other hand, those who really are suffering from a serious psychiatric disorder, run the risk of their problems being overlooked by the probation officer, with inevitable consequences, namely that the SOV regulation is in danger of being imposed on the wrong target group. This explains the plea, therefore, for double-reporting in every case, i.e. a consultation letter from the Forensic Psychiatric Service by a forensic psychiatrist, combined with a psychiatric and/or psychological Pro Justitia examination in the second stage. In practice, this means that a psychological report will usually suffice. This is largely determined by pragmatic and logistical considerations, such as the lack of time available to make an official submission for SOV and to implement it, or the limited availability of (psychiatric or psychological) reporters. Even if the Public Prosecutor is satisfied with the consultation letter, it would still be inappropriate, from a behaviour-expert viewpoint, to regard the consultation letter in terms of an informatory and advisory guideline on which the judge can think and act, as being equal to a Pro Justitia report (see my earlier comments: the legal credence of the Pro Justicia report in respect of the examination of the justiciable cannot be tampered with, despite the guideline role of the Letter Report or the consultation letter. See Oei 1998). 
If a FPS consultation letter is only available in the case of a psychiatric disorder, or when a seriously psychiatrically disturbed addict standing trial for an illegal offence refuses to undergo a behaviour-expert examination, the court will often make a demand for double-reporting in such a case. This is always disadvantageous for the accused, bearing in mind that extension of his temporary detention does not favour the start of the SOV -the temporary detention is extended, and the judge is not bound to deduct it from the total duration of the sentence. The SOV is a fairly heavy sentence, comparable in fact to a three year prison term (Vegter 2001b). Felons on whom, in normal practice, a sentence of no more than a few months would be imposed, may find themselves facing two years in jail. This then raises questions about the proportionality of the regulation. The legitimacy of the SOV decreases if the 'nuisance' criterion takes precedence over social reintegration. That the 'nuisance' element constitutes a clear indication for the imposition, or continuation, of the SOV, cannot be denied. It is doubtful, however, if TBS and SOV are of the same order. The SOV is primarily a 'nuisance' regulation, and less a 'safety' regulation, bearing in mind that the presence of a serious psychiatric disorder constitutes a contra-indication for its imposition -this in contrast to the conditions attached to the imposition of a TBS sentence. Furthermore, in the case of a SOV sentence, it is more a matter of obligatory detention, rather than obligatory nursing care, such as is the case in a TBS sentence, and even less a question of obligatory treatment. In this sense, the $\mathrm{SOV}$ is more a matter of depriving the detainee of his liberty. If the detainee refuses to cooperate in the care and treatment programme, he can be detained for a maximum of two years, and thereby run the risk of his addiction problem not being solved.
It is for this reason, therefore, that a reliable behaviour-expert examination should take place before the SOV regulation is imposed, on the proviso that there are no contra-indications, such as serious psychiatric pathology. Problems can also arise, from a behaviour-expertise point of view, when chronic addicts are considered for SOV, whilst all they want is food and a roof over their heads, are not seeking to 'kick' the drug habit, or are insufficiently motivated for it. There are also problems surrounding the question of whether the SOV regulation is actually used solely, or primarily, to put nuisance-element justiciables (temporarily) behind bars.

\section{In conclusion}

Although the SOV regulation may appear to be a purely (soft?) political instrument, the actual (hard) signs of mental health and mental functioning must be determined by a behaviour-expert, and -if the FPS consultation letter so advises- to do that on the basis of a psychiatric and/or psychological test examination. The combination of a consultation letter and a psychological examination is the minimum requirement, prior to advising the imposition of the SOV regulation. SOV can only be effective if there are enough behaviour-expert arguments to support it. The role of the supervisor is absolutely crucial here (SOV Rotterdam 2001). Furthermore, some matters which still remained unclear after the first SOV court cases, have not yet been resolved. In the case of $\mathrm{M}$, for instance, the accused expressed interest in SOV, despite a serious psychiatric disorder. The case was adjourned, because the court required double-reporting in order to be able to decide on the question of culpability, and 
so that possible contra-indications for the imposition of the SOV regulation could be investigated. Perhaps the court saw the possibility of compulsory legal in-patient admittance to a General Psychiatric Hospital (art. $37, \mathrm{PC}$ ) as an alternative to SOV. In the case of $\mathrm{B}$, the accused refused to cooperate, and protested his innocence of the crime of which he was accused. The SOV regulation was later imposed in this case, nonetheless, bearing in mind the availability of a behaviourexpert examination carried out in respect of an earlier case brought against the defendant, plus the fact that he was a known repeated offender. SOV was imposed in the case of S; despite the fact that only the FPS consultation letter was available in this case, the accused was still prepared to accept SOV -and a Bouman House report was also to hand. The case of $\mathrm{K}$ was adjourned because of the need for supplementary medicalbehaviour-expert examinations, in view of the fact that the accused decided later to accept SOV, on condition that he needed methadon for medical reasons.

The sum total of all this is that the field of behaviour-expertise is challenged to remain alert to ensure that the proper conditions exist whereby justiciables are guaranteed the treatment they need.

\section{References}

Crome IB. Addiction and the future of addiction psychiatry. Psychiatr Bull 2001; 25: 242-243.
Ekelemburg DH. De SOV Bekneld tussen penitentiaire regels [The SOV trapped between penitentiary rules]. Sancties 2001: 332-338.

Hofstee EJ. TBR en TBS. Deventer: Kluver; 1987: 123 [mentioned by Kelk C, Delikt en Dlinkwent 2002; 32: 209].

Kelk C. De perpectieven van de SOV [The perspectives of the SOV]. Sancties 1999: 208 et seq.

Kooijmans T. Strafrechtelijke opvang verslaafden [Legal detention of addicts]. Delikt en Dlinkwent 2000: 593-609.

Mevis PAM. Vriheidsbeneming ter bestrijding van overlast: inderdaad uniek dregsleleid [Deprivation of liberty in order to combat disorder in society: a unique drugs policy indeed]. Sancties $1996:$ 208-220.

Oei TI. De rapportagetaak van de districtpsychiater [The reporting task of the district psychiatrist] Process 1998: 150-152.

Oei TI. De ontkennende verdachte ten onrechte in de beklaagdenbank? Process 2001: 157-158.

SOV, een maatregel met perspectief ( $S O V$, a regulation with perspectives). Final report. SOV Rotterdam 2001: 23 et seq.

van Kalmthout AM. Over de SOV [about the SOV] Psychiatric symposium 't Spant, the Nederlands, September 2000 [See Medisch Contact, 2000; 55(37): 1272-1274].

van Kordelaar WF. When and how can the forensic expertise be used. Deventer: Kluver; 2002.

Vegter PC. Rechter en stranfrechtelikjke opvanf verslaandaf [The judge and the legal detention of addicts]. Sancties 2001a: 65-68.

Vegter PC. Een nieuwe maatregel: Strafrechtelijke Opvang Verslaafden [A new neasure: Legal Detention of Addicts]. In: Lünneman KD, Schuyt PM and van Wifferen (eds.). Diversiteit van sanctionering [Diversity of sanctioning], Gouda: Quint Deventer, 2001: 59 et seq.

Vrolijk M. Standen en landen [Ranks and lands]. Thesis, University of Nijmegen (The Netherlands), 2001. 


\section{Linguistics \& Language Behavior Abstracts}

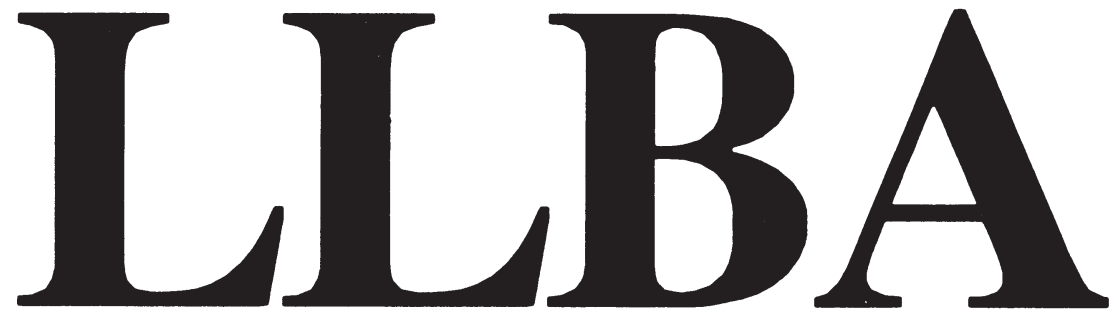

Now entering our 26 th year $(135,000$ abstracts to date) of senvice to linguists and language researchers worldwide. LLBA is available in print and also online from BRS and Dialog.

\section{Linguistics \& Language Behavior Abstracts}

$$
\text { P.O. Box } 22206
$$

San Diego, CA 92192-0206

Phone (619) 695-8803 FAX (619) 695-0416

Fast, economical document delivery available. 